Article

\title{
Analyzing Precision Agriculture Adoption across the Globe: A Systematic Review of Scholarship from 1999-2020
}

\author{
Chin-Ling Lee ${ }^{1}\left(\mathbb{D}\right.$, Robert Strong ${ }^{2, *(\mathbb{D})}$ and Kim E. Dooley ${ }^{2}(\mathbb{D}$ \\ 1 Taoyuan District Agricultural Research and Extension Station, Council of Agriculture, \\ Taoyuan 32745, Taiwan; chinling@tydais.gov.tw \\ 2 Department of Agricultural Leadership, Education, and Communications, Texas A\&M University, \\ College Station, TX 77843, USA; k-dooley@tamu.edu \\ * Correspondence: r-strong@tamu.edu
}

Citation: Lee, C.-L.; Strong, R.; Dooley, K.E. Analyzing Precision Agriculture Adoption across the Globe: A Systematic Review of Scholarship from 1999-2020. Sustainability 2021, 13, 10295. https:// doi.org/10.3390/su131810295

Academic Editors: Alexa Lamm and Marc A. Rosen

Received: 16 June 2021

Accepted: 9 September 2021

Published: 15 September 2021

Publisher's Note: MDPI stays neutral with regard to jurisdictional claims in published maps and institutional affiliations.

Copyright: (c) 2021 by the authors. Licensee MDPI, Basel, Switzerland. This article is an open access article distributed under the terms and conditions of the Creative Commons Attribution (CC BY) license (https:/ / creativecommons.org/licenses/by/ $4.0 /)$.

\begin{abstract}
Precision agriculture (PA) is a holistic, sustainable, innovative systems approach that assists farmers in production management. Adopting PA could improve sustainable food security and community economic sustainability. Developing an understanding of PA adoption attributes is needed in order to assist extension practitioners to promote adoption and better understand the innovation adoption phenomena. A systematic review of literature was conducted to investigate attributes that foster PA adoption. Thirty-three publications were examined, and four themes were found among the reviewed publications. The results were interpreted using Rogers' diffusion of innovations framework to address the research objectives. Relative advantage and compatibility were two dominant attributes needed to strengthen the adoption of PA, and the complexity attribute was rarely communicated to promote the adoption of PA. The systematic review indicated the rate of farmer's PA adoption does not occur at the highest potential levels due to inadequate communication of PA attributes from change agents to farmers. Extension field staff need professional development in communicating the five PA adoption attributes to farmers in order to improve PA adoption and enhance local sustainable food security. Thus, authors recommend future complexity studies from agricultural extension specialists' perspectives to comprehend demonstratable approaches to motivate farmers' adoption of PA.
\end{abstract}

Keywords: precision agriculture; agricultural extension; profitability; production quality; systematic review

\section{Introduction}

The UN adopted new Sustainable Development Goals aiming to end poverty, protect the planet, and ensure prosperity for all. In order to reach these goals, there is a need for long-term impact and large-scale influence [1]. Local partners know the problems they face and seek potential solutions. Adoption of a new approach (innovation) should have an observable advantage over previous techniques, allow for trialability, and fit into the local culture and resources availability. How can empirical research in journals be communicated effectively to stakeholders? There is a need for social and behavioral scientists to serve in translation science roles to help reach these goals.

Precision agriculture technology adoption is attracting more attention as a solution in food production to feed a growing population [2]. The history of agricultural development shows that the adoption of innovative technologies has been one of the essential factors in the growth of agricultural production systems [3-5]. Wolde et al. [6] recommended the 2050 Food Challenge necessitates global science-based innovations that concentrate on sustainable agricultural practices that support healthful dietary solutions.

From the perspective of information flow, the diffusion process of agricultural technology innovation involves government units, agricultural research and extension units, agricultural marketing units, media units, and consumers. Agricultural extension plays 
an important role in the development [7] and knowledge transfer [8] of innovations that sustain agricultural productivity. There are increased efforts from agricultural extension to promote precision agriculture (PA) in production contexts, such as viticulture to improve sustainability in Italy [9]. In Nigerian drylands, agricultural extension has been promoting precision approaches to teach fertilizer application [10]. Pluralized agricultural extension is perpetually faced with sustainability issues such as precision farming due to the cautious nature of farmers toward change [11].

PA technology is a management tool for monitoring the efficiency of resource inputs while reducing chemical use to avoid environmental damage and produce high quality products to satisfy growing demand on food $[12,13]$. Precision farming is a holistic, innovative systems approach that assists farmers in managing crop and soil variability to decrease costs, improve yield quality and quantity, and enhance farm income [14]. PA applies traditional farming practices with new technology, practices, and economic drivers to enhance sustainability in a dynamic balance [15]. Studies have reported positive outcomes from PA adoption, including economic savings in productivity factors [16], increasing yield and environmental sustainability [17], and improving food security and community economic vitality in developing regions [18]. The International Society for Precision Agriculture (ISPA) provides clarity and guidance on this important concept, to achieve the agricultural production quality, create production profits, and improve the efficiency of resource use and environmental sustainability [19]. Developing an understanding of PA adoption attributes is necessary in order to assist extension practitioners in the promotion and adoption of PA. Empirical evidence is needed for stakeholders to adopt this innovation [20].

The history of agricultural development suggests the adoption of innovative technologies has been a critical factor to improve sustainable livelihoods. However, several studies specified that the adoption rates of PA were low [21-23]. Decisions by farmers to adopt new technologies are multifaceted. PA adoption processes are complicated, and the intricacies exist in diverse elements and interactions [24]. Farmers are intrigued by PA innovations but are less convinced of its value even though they believe that PA technologies are useful to farming $[25,26]$. Barriers to PA adoption included technical issues with equipment, access to service software, the lack of compatibility of equipment to current farm operations [27], concerns regarding service providers misuse of agricultural data, challenges of managing the amount of PA data [28], user-friendly designs [10] and the cost [29,30].

Rogers' [31] diffusion of innovation was applied as the theoretical framework to determine whether research on PA included adoption features that impact the rate of adoption. Adoption refers to the decision to make full use of the innovation as the best available course of action, while rejection refers to the decision not to adopt an innovation. In adopting PA, knowledge and competences are required to acquire and manage data on farms [28]. Extension participants' knowledge increased when taught PA innovations through hands-on experiences with software, coupled with instructor guided and self-directed instruction [32].

Rogers' [31] five perceived attributes include relative advantage, compatibility, complexity, trialability, and observability. These attributes show research on farmers' adoption of PA factors can be impacted by extension specialists' workshops and training programs. Relative advantage, the first persuasion attribute, refers to the degree to which innovation is perceived as being better that to an existing idea or technology it replaced. The second attribute, compatibility, represents the degree to which innovation aligns with existing technology, past experience, and the needs of potential adopters. The third persuasion attribute, complexity, is the degree to an individual perceived as the relative difficulty of understanding and using an innovation. The fourth attribute is trialability, which is the degree to which an innovation may be tested. Observability, the last attribute, is the degree to which the results of an innovation can be seen by others.

A study on PA adoption by Lowerberg-DoBoer and Erickson [26] indicated that most research was aimed at understanding the factors of PA adoption at the farm level. Previous studies found that the use of PA was associated with higher production and profits [33,34]; however, whether the adoption factors related to yield and profit depended on the develop- 
ment of agricultural extension systems. There are few studies on the relationship between agricultural extension systems and PA technology adoption. Therefore, it is necessary to review the literature to examine the development of PA technology for evidenced-based decisions and translational science to promote adoption through extension systems to stakeholders.

This study implemented a systematic literature review over the last 20 years to determine PA adoption attributes for extension agents to improve sustainability among farmers. There were three research questions that guided this study: (a) What were the common adoption attributes promoting PA? (b) What were the main crop varieties in promoting PA adoption? and (c) What countries were represented? This systematic literature review describes current trends and future directions in promoting PA adoption.

\section{Materials and Methods}

A systematic review is a method using an exhaustive and comprehensive search based on explicit and strict protocols to review the existing literature with a synthesis of data focusing on a topic or on related key questions [35]. There were five steps utilized to collect, analyze, and interpret literature in this study. The first step was to identify the critical question of the research. Then, the researchers formulated the search parameters of the data selection procedure. The third step was to implement the systematic search procedure in the database. Data analysis was the fourth step, and the interpretation and summary of the materials were undertaken in the fifth step [36].

There were a variety of words employed to describe PA, including precision agriculture, precision farming, smart farming, smart agriculture, climate-smart farming, etc. Data collected from databases such as ScienceDirect with these terms were not specific enough. The intent was to investigate the trends of PA diffusion, not the characteristics or application of PA. Therefore, to obtain the targeted literature, the researchers chose Precision Agriculture, the premiere journal publishing PA scholarship, to conduct their electronic search. Precision Agriculture provides an effective forum for the dissemination of original research on topics in the rapidly evolving context of PA.

To understand the characteristics and role of the agricultural extension system in promoting PA, the researchers selected 12 journals focusing on the field of agricultural extension with the keyword, "precision agriculture." Six extension journals were identified by SCOPUS through a title search with extension as a keyword; Journal of Agricultural Education and Extension, Journal of Extension, Journal of Agricultural Extension, Agricultural Administration and Extension, International Journal of Agricultural Extension, and Journal of International Agricultural and Extension Education. However, none of these SCOPUS identified extension journals had literature respective to PA adoption in the last 20 years. The researchers expanded their systematic review to six additional extension focused journals that had published agricultural technology adoption studies all over the world; Journal of Extension and Human Sciences, Journal of Extension Systems, Journal of Extension Education, Journal of Agricultural Extension Management, Journal of Extension and Research, and Journal of Agricultural Extension and Rural Development. The additional six extension focused journals produced zero publications respective to PA adoption. Results were filtered by key terms and publication dates from 1999 to 2020 to ensure unbiased samples were collected. Precision Agriculture was the only journal in the systematic review's thirteen journal assessment of 20 years that produced PA adoption inquiries within this study's parameters and keywords.

The terms (T) and combinations (C) authors utilized for literature search were displayed in Table 1.

Literature was collected whose titles met the following themes on the publication title: (1) Production quality; (2) Improved profitability; (3) Improved the efficiency of resource use; and (4) Environmental sustainability. The themes were taken under the definition of PA by the ISPA (ISPA, 2019). These themes were selected based on the purpose of this study. Since our aim was to find the research that focused on PA adoption based on the attributes of PA. The research team established a set of code definitions and data collecting criteria (see Table 2). 
Table 1. Terms and Combinations for Literature Search.

\begin{tabular}{cccc}
\hline & T1: Production & T2: Quality & T3: Yield \\
T4: Crop & T5: Profitability & T6: Profit \\
T7: Efficiency & T8: Resource & T9: Benefit \\
Terms & T10: Effectiveness & T11: Investments & T15: Environment \\
& T13: Worker & T14: Sustainability & T18: Precision agriculture \\
& T16: Impact & T17: Reduce & C3: T3 and T4 \\
& C1: T1 and T2 & C2: T2 and T3 & C6: T9 and T10 \\
\hline \multirow{3}{*}{ Combinations } & C4: T3 and T6 & C5: T7 and T8 & \\
& C7: T15 and T16 & C8: T16 and T17 & \\
\hline
\end{tabular}

Table 2. Descriptions of Coded Themes in the Systematic Review's Data Collection Process.

\begin{tabular}{|c|c|c|}
\hline Coded Theme & & Data Collection Process \\
\hline $\begin{array}{l}\text { Production } \\
\text { quality }\end{array}$ & $\begin{array}{l}\text { i } \\
\text { ii } \\
\text { iii }\end{array}$ & $\begin{array}{l}\text { Production and quality were keyword searches in publication titles in the journal and there were no results. } \\
\text { Yield and quality were search keywords in journal titles and nine results were generated. } \\
\text { Crop and quality were the key terms used to search in the title of publications and there were two articles fitting the } \\
\text { search term, but they were identical articles from the first search. }\end{array}$ \\
\hline $\begin{array}{l}\text { Improved } \\
\text { profitability }\end{array}$ & $\begin{array}{l}\text { i } \\
\text { ii } \\
\text { iii }\end{array}$ & $\begin{array}{l}\text { Profitability was the key term search in the title and nine results were produced. } \\
\text { Profit was utilized as a key term to search for the articles and there were two results fitting the search term. } \\
\text { Profit and yield to search for articles and one article which was the same as the previous search in the theme one. }\end{array}$ \\
\hline $\begin{array}{l}\text { Improved the } \\
\text { efficiency of } \\
\text { resource use }\end{array}$ & $\begin{array}{l}\text { i } \\
\text { ii } \\
\text { iii } \\
\text { iv }\end{array}$ & $\begin{array}{l}\text { Efficiency and resource generated zero results. } \\
\text { Efficiency produced six results, but there was one article which was the same as the previous search in theme two. } \\
\text { Benefit and effectiveness revealed three articles and one search result indicated effectiveness. } \\
\text { Based on the definition of PA, resource use includes human and material resources; hence, we further used key terms, } \\
\text { investments, labor, and worker, to do the title search separately, and there were still zero results. }\end{array}$ \\
\hline $\begin{array}{l}\text { Environmental } \\
\text { sustainability }\end{array}$ & $\begin{array}{l}\mathrm{i} \\
\mathrm{ii} \\
\mathrm{iii}\end{array}$ & $\begin{array}{l}\text { Sustainability produced three results in titles. } \\
\text { Environment and impact had zero results. } \\
\text { Reduce and impact also had zero results. }\end{array}$ \\
\hline
\end{tabular}

\subsection{Inclusion/Exclusion Criteria}

Each article that met the coded themes was examined and were either included or excluded from further investigation based upon the following criteria: (a) publication type was peer-reviewed article that written in English; (b) search terms appearing in the title of articles; and (c) articles must be published between 1999 and 2020. Table 3 displays the implemented criteria for the systematic review.

Table 3. Eligibility Criteria for the review.

\begin{tabular}{cc}
\hline Inclusion Criteria & Exclusion Criteria \\
\hline Publication type was a peer-reviewed article & Publication type was nonpeer-review \\
Articles were written in English & Articles were not written in English \\
Search terms appearing in the title of articles & Search terms other than in the title \\
Published in the period (1999-2020) & Published prior to 1999 \\
\hline
\end{tabular}

\subsection{Data Extraction}

There were 38 articles from the combination of keyword searches needed for further eligibility screening. Six duplicate studies, and one book review article were excluded from the data analysis after the second review. As a result, 31 publications were investigated.

Five elements of the articles were documented, including the title, the crop varieties examined in the respective article, the region in which the study was conducted, the number of research keywords used, and the unveiled innovation attributes respective to PA. Data were extracted manually following a review of each full-text of publication and recorded into an Excel spreadsheet to analyze.

\subsection{Data Analysis}

After data collection, all the publications were analyzed with the crop varieties, regions, and keyword co-occurrence to provide descriptive statistics with narrative explanations. Three researchers provided interrater reliability in the analysis process. A VOSviewer tool was used to calculate the number of publications in which two keywords appeared together in the title, 
abstract, or keyword list. VOSviewer creates a cluster analysis. Clustering is a method that has the advantage of setting objects into a group by similarity or dissimilarity [37]. In general, keywords with high relevance tend to be grouped into the same cluster. Node size is related to the frequency of occurrence. The smaller the node, the lower the frequency of occurrence. The line describes the linkage between two keywords, which presented the connection between two keywords appearing in the same article. The thicker line means the stronger connection between the two keywords [38]. In this study, authors conducted a network analysis to display the trend and current status of researchers in promoting PA.

\section{Results}

Based on the systematic review, 31 publications were identified that met the coding criteria. The analysis was considered based on (a) publications productivity, (b) crop varieties, (c) regions, and (d) keyword frequency. Twelve selected agricultural extension journals matched the data extraction criteria. From Precision Agriculture volumes 1 through 22 , there were 31 articles whose titles met the keywords in four coded themes on the publication title. Two of the 31 articles met the selection criteria in two different coded themes. Figure 1 shows the preferred data selection item for systematic reviews.

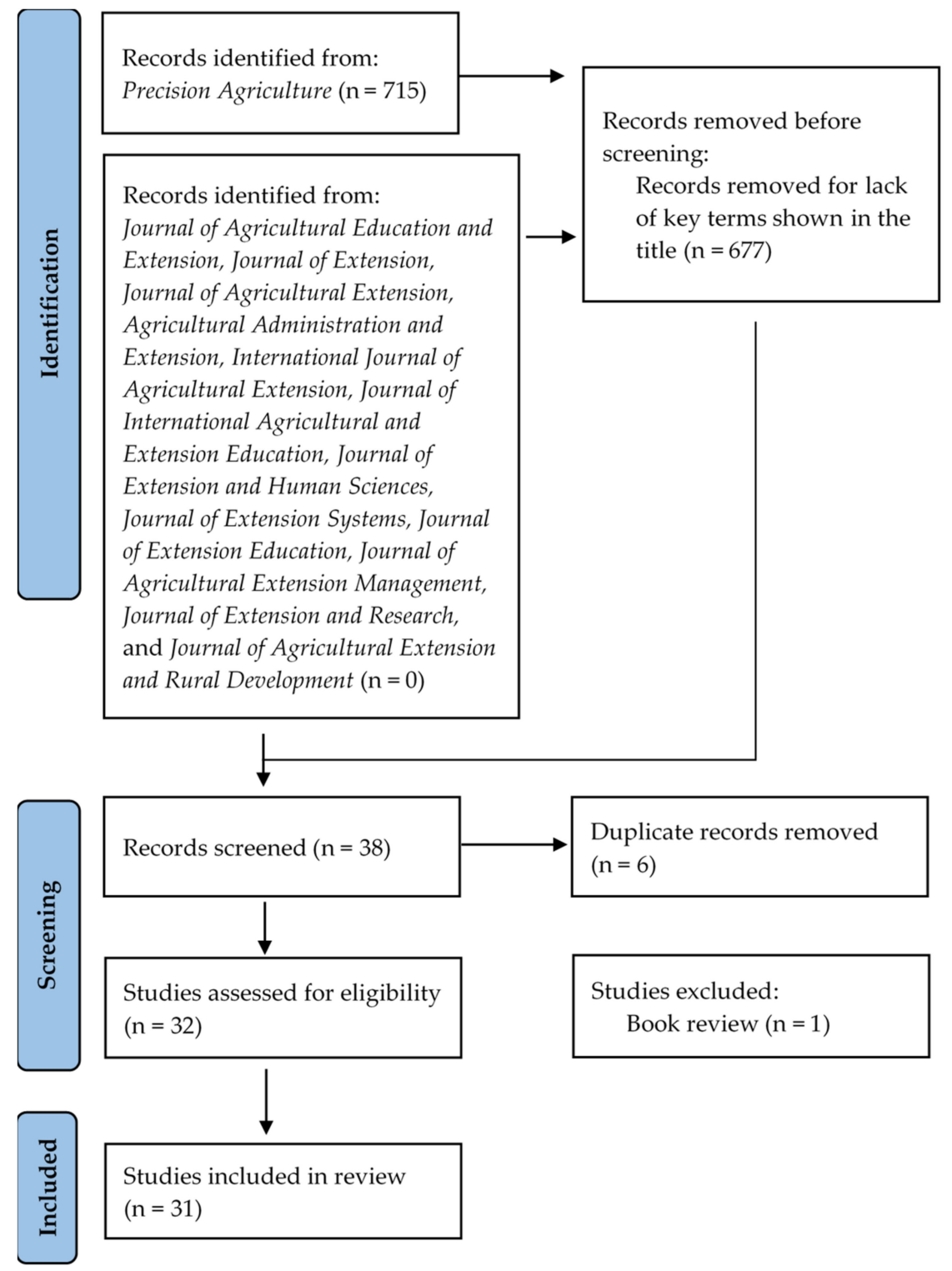

Figure 1. PRISMA flow diagram of data selection procedure. 


\subsection{Summary of Findings}

Among the literature investigated $(n=33)$, improved profitability was the most published PA adoption theme. Twelve ( $n=12,36.4 \%$ ) publications indicated improved profitably was the dominant characteristic to promote the adoption of precision agriculture as illustrated in Table 4 . Improved proficiency use was the second theme $(n=10,30 \%$, production quality was the third ranking theme $(n=9,27.3 \%)$, and the final PA adoption theme was environmental sustainability $(n=2,6.1 \%)$. The overall mean and standard deviation for the four PA adoption themes were $(M=2.97, S D=0.95)$ on the four-point anchored scale.

Table 4. Literature Analyzed Under the Coded Theme Improved Profitability.

\begin{tabular}{|c|c|c|c|}
\hline Literature & Title & Crop & Country \\
\hline Karatay and Meyer-Aurich [39] & $\begin{array}{l}\text { Profitability and downside risk implications of site-specific nitrogen } \\
\text { management with respect to wheat grain quality }\end{array}$ & wheat & Germany \\
\hline Mills et al. [40] & The profitability of variable rate lime in wheat & wheat & USA \\
\hline Stamatiadis et al. [41] & $\begin{array}{l}\text { Variable-rate application of high spatial resolution can improve cotton N-use } \\
\text { efficiency and profitability }\end{array}$ & cotton & Greece \\
\hline Yost et al. [42] & A long-term precision agriculture system sustains grain profitability & $\begin{array}{l}\text { corn; } \\
\text { soybean }\end{array}$ & USA \\
\hline Stefanini et al. [43] * & $\begin{array}{c}\text { Effects of optical sensing based variable rate nitrogen management on yields, } \\
\text { nitrogen use and profitability for cotton }\end{array}$ & cotton & USA \\
\hline Tona et al. [44] & $\begin{array}{l}\text { The profitability of precision spraying on specialty crops: a technical-economic } \\
\text { analysis of protection equipment at increasing technological levels }\end{array}$ & $\begin{array}{l}\text { grapevine; } \\
\text { apple }\end{array}$ & $\begin{array}{l}\text { Central- } \\
\text { Southern } \\
\text { Europe }\end{array}$ \\
\hline Larson et al. [45] & $\begin{array}{l}\text { Effect of field geometry on profitability of automatic section control for chemical } \\
\text { application equipment }\end{array}$ & cotton & USA \\
\hline Boyer et al. [46] & Profitability of variable rate nitrogen application in wheat production & wheat & USA \\
\hline Maine et al. [47] & $\begin{array}{l}\text { Impact of variable-rate application of nitrogen on yield and profit: a case study } \\
\text { from South Africa }\end{array}$ & $\mathrm{N} / \mathrm{A}$ & South Africa \\
\hline O’Neal et al. [48] & $\begin{array}{l}\text { Profitability of On-Farm Precipitation Data for Nitrogen Management Based on } \\
\text { Crop Simulation }\end{array}$ & $\begin{array}{l}\text { corn; } \\
\text { soybean }\end{array}$ & USA \\
\hline Young et al. [49] & Site-Specific Herbicide Decision Model to Maximize Profit in Winter Wheat & wheat; peas & USA \\
\hline Reyns et al. [50] & Site-Specific Relationship Between Grain Quality and Yield & wheat & Belgium \\
\hline
\end{tabular}

* Duplicate record.

The theme of improving the efficiency of resource use was published the second most commonly, in 10 articles $(n=10,30.3 \%)$ as presented in Table 5 .

Table 5. Literature Analyzed Under the Coded Theme Improved the Efficiency of Resource Use.

\begin{tabular}{|c|c|c|c|}
\hline Literature & Title & Crop & Country \\
\hline Stamatiadis et al. [41] * & $\begin{array}{l}\text { Variable-rate application of high spatial resolution can improve cotton } \mathrm{N} \text {-use efficiency } \\
\text { and profitability }\end{array}$ & cotton & Greece \\
\hline Martinez et al. [51] & $\begin{array}{l}\text { A cost-effective canopy temperature measurement system for precision agriculture: a } \\
\text { case study on sugar beet }\end{array}$ & $\begin{array}{l}\text { sugar } \\
\text { beets }\end{array}$ & Spain \\
\hline Pavuluri et al. [52] & Canopy spectral reflectance can predict grain nitrogen use efficiency in soft red winter wheat & wheat & USA \\
\hline Ampatzidis et al. [53] & $\begin{array}{c}\text { Portable weighing system for monitoring picker efficiency during manual harvest of } \\
\text { sweet cherry }\end{array}$ & $\begin{array}{l}\text { cherry } \\
\text { tree }\end{array}$ & USA \\
\hline Ortiz et al. [54] & $\begin{array}{l}\text { Evaluation of agronomic and economic benefits of using RTK-GPS-based auto-steer } \\
\text { guidance systems for peanut digging operations }\end{array}$ & peanut & USA \\
\hline Go'mez-Cando'n et al. [55] & $\begin{array}{l}\text { Sectioning remote imagery for characterization of Avena sterilis infestations. Part B: } \\
\text { Efficiency and economics of control }\end{array}$ & wheat & Spain \\
\hline Rascher and Pieruschka [56] & $\begin{array}{l}\text { Spatio-temporal variations of photosynthesis: the potential of optical remote sensing to } \\
\text { better understand and scale light use efficiency and stresses of plant ecosystems }\end{array}$ & $\begin{array}{l}\text { soybean; } \\
\text { avocado }\end{array}$ & USA \\
\hline Torbett et al. [57] & $\begin{array}{l}\text { Perceived importance of precision farming technologies in improving phosphorus and } \\
\text { potassium efficiency in cotton production }\end{array}$ & cotton & USA \\
\hline Biermacher et al. [58] & Maximum benefit of a precise nitrogen application system for wheat & wheat & USA \\
\hline Krell and Pedigo [59] & $\begin{array}{c}\text { Comparison of Estimated Costs and Benefits of Site-Specific Versus Uniform } \\
\text { Management for the Bean Leaf Beetle in Soybean }\end{array}$ & $\begin{array}{l}\text { soybean- } \\
\text { corn } \\
\text { rotation }\end{array}$ & USA \\
\hline
\end{tabular}


Furthermore, nine $(n=9,27.3 \%)$ articles have been published on production quality, which are exhibited in Table 6.

Table 6. Literature Analyzed Under the Production Quality Coded Theme.

\begin{tabular}{|c|c|c|c|}
\hline Literature & Title & Crop & Country \\
\hline Holland et al. [60] & $\begin{array}{l}\text { Proximal fluorescence sensing of potassium responsive crops to develop improved } \\
\text { predictions of biomass, yield and grain quality of wheat and barley }\end{array}$ & $\begin{array}{l}\text { wheat; } \\
\text { barley }\end{array}$ & Australia \\
\hline Uribeetxebarria et al. [61] & $\begin{array}{l}\text { Stratified sampling in fruit orchards using cluster-based ancillary information maps: a } \\
\text { comparative analysis to improve yield and quality estimates }\end{array}$ & peach & Spain \\
\hline Arno et al. [62] & $\begin{array}{l}\text { Spatial variability in grape yield and quality influenced by soil and crop } \\
\text { nutrition characteristics }\end{array}$ & grape & Spain \\
\hline Aggelopulou et al. [63] & Spatial variation in yield and quality in a small apple orchard & apple & Greece \\
\hline Link et al. [64] & $\begin{array}{l}\text { Evaluation of current and model-based site-specific nitrogen applications on wheat } \\
\text { (Triticum aestivum L.) yield and environmental quality }\end{array}$ & wheat & Germany \\
\hline Jørgensen and Jørgensen [65] & Uniformity of wheat yield and quality using sensor assisted application of nitrogen & wheat & Denmark \\
\hline Miao et al. [66] & $\begin{array}{l}\text { Spatial variability of soil properties, corn quality and yield in two Illinois, USA fields: } \\
\text { implications for precision corn management }\end{array}$ & corn & USA \\
\hline Miao et al. [67] & $\begin{array}{l}\text { Identifying important factors influencing corn yield and grain quality variability using } \\
\text { artificial neural networks }\end{array}$ & corn & USA \\
\hline Reyns et al. [50]* & Site-Specific Relationship Between Grain Quality and Yield & wheat & Belgium \\
\hline
\end{tabular}

Environmental sustainability was the least published $(n=2,6 \%)$ adoption construct from the systematic review analysis (see Table 7).

Table 7. Literature Analyzed Under the Coded Theme Environmental Sustainability.

\begin{tabular}{cccc}
\hline Literature & Title & Crop & Country \\
\hline Kountios et al. [68] & $\begin{array}{c}\text { Educational needs and perceptions of the sustainability of precision } \\
\text { agriculture: survey evidence from Greece }\end{array}$ & $\begin{array}{c}\text { cotton; } \\
\text { vegetable; } \\
\text { cereal }\end{array}$ & $\begin{array}{c}\text { Greece } \\
\text { Bongiovanni et al. [69] }\end{array}$ \\
\hline
\end{tabular}

There were thirty-nine $(n=39)$ varieties of crops produced from the review. Wheat $(n=11,28.2 \%)$ was the most PA produced crop, followed by corn $(n=6,15.4 \%)$, cotton $(n=5,13 \%)$, soybean $(n=4,10.3 \%)$, grape and apple each earned $n=2,5.1 \%$, and sugar beets, cherry, vegetable, cereal, peach, peanut, avocado, barley, and peas $n=1,2.6 \%$ were identical from the systematic review of the literature (see Figure 2).

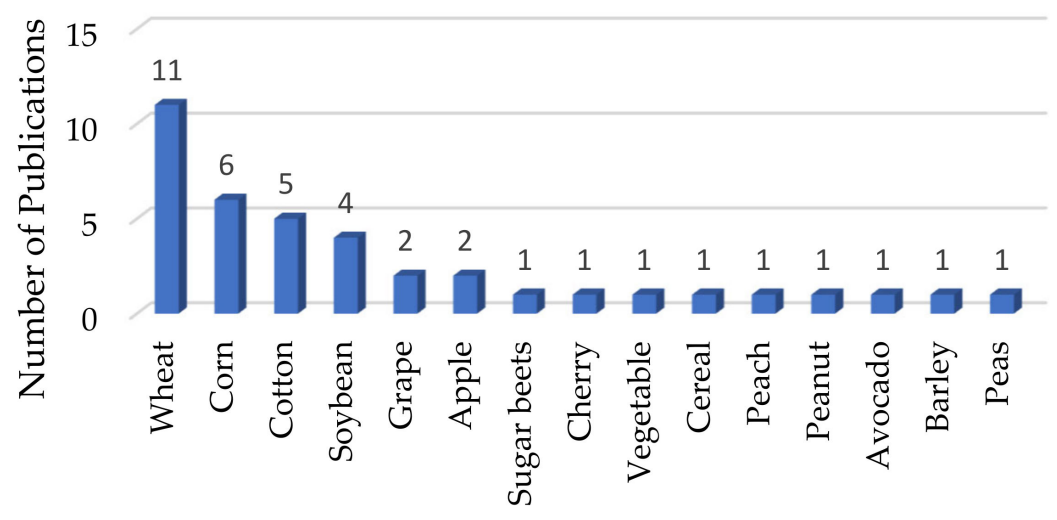

\section{Crop Variety}

Figure 2. Distribution by crop variety. 
The published inquiries occurred in developed regions. The majority of the thirty-one ( $n=31)$ PA studies $(n=16,51.6 \%)$ were conducted in the United States. The complete analysis of the number of published studies in respective regions were USA $n=16,51.6 \%$, Spain $n=4,13 \%$, Greece $n=3,9.7 \%$, Germany $n=2,6.5 \%$, Argentina $n=1,3.2 \%$, Australia $n=1,3.2 \%$, Belgium $n=1,3.2 \%$, Central-South Europe $n=1,3.2 \%$, Denmark $n=1,3.2 \%$, and South Africa $n=1,3.2 \%$ (see Figure 3).

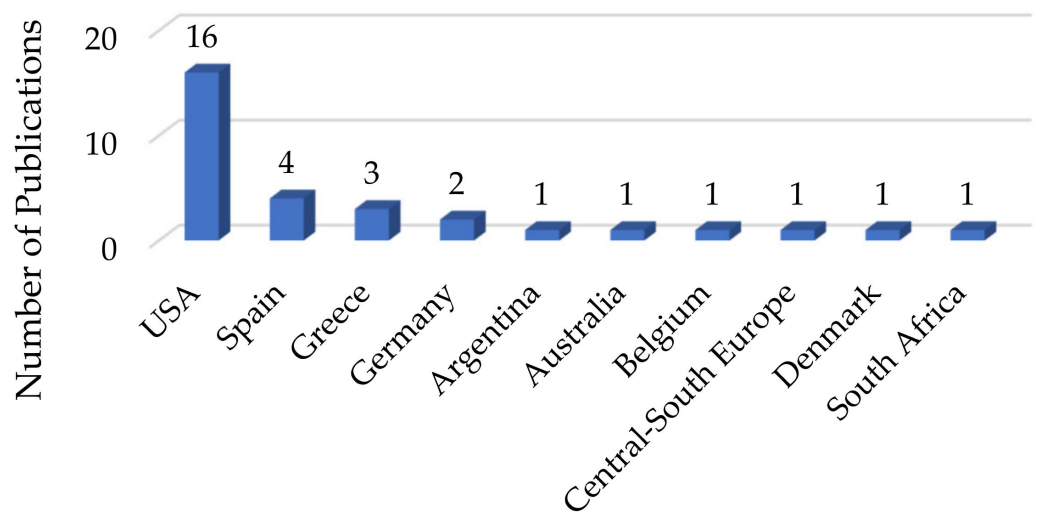

\section{Regions}

Figure 3. Distribution by Regions.

The VOSviewer tool was utilized to understand the variety of keywords used by researchers frequently in Precision Agriculture. The results indicated the number of publications in which 12 major keywords occurred together more than five times in the title, abstract, or keyword list, producing a total strength co-occurrence linkage of 110 . The results indicated that the majority of publications had used these keywords, as depicted in Figure 4.

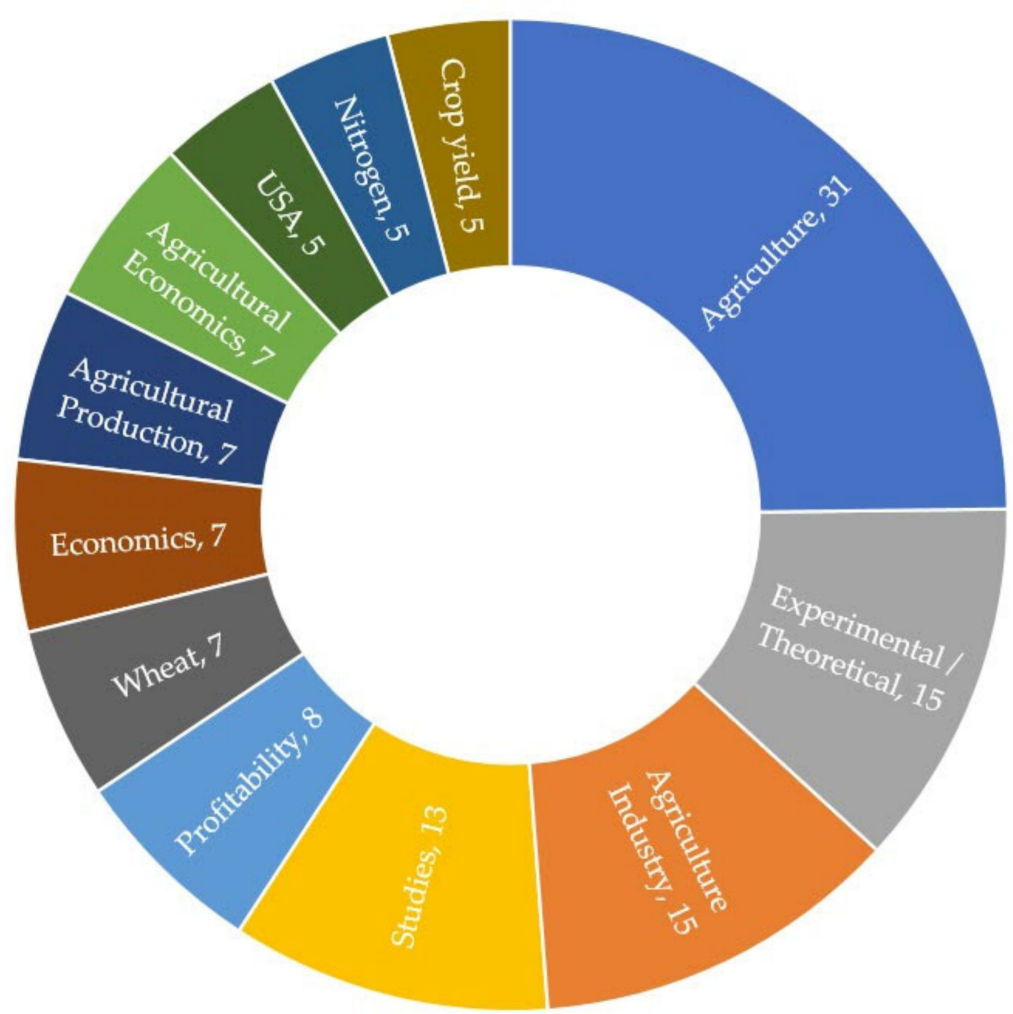

Figure 4. Number of publications keywords are presented. 
VOSviewer revealed the connection of research keywords for PA. The size of nodes represented the frequency of keywords. The larger size of the node is the larger frequency count. As illustrated in Figure 5, the Agriculture node has the largest frequency of keywords and was double in size compared to the second ranked keywords. Profitability, crop, and agricultural economics also had higher frequencies. These three main clustered sections (green, red, and blue) are primarily the themes researchers found promoted PA adoption.

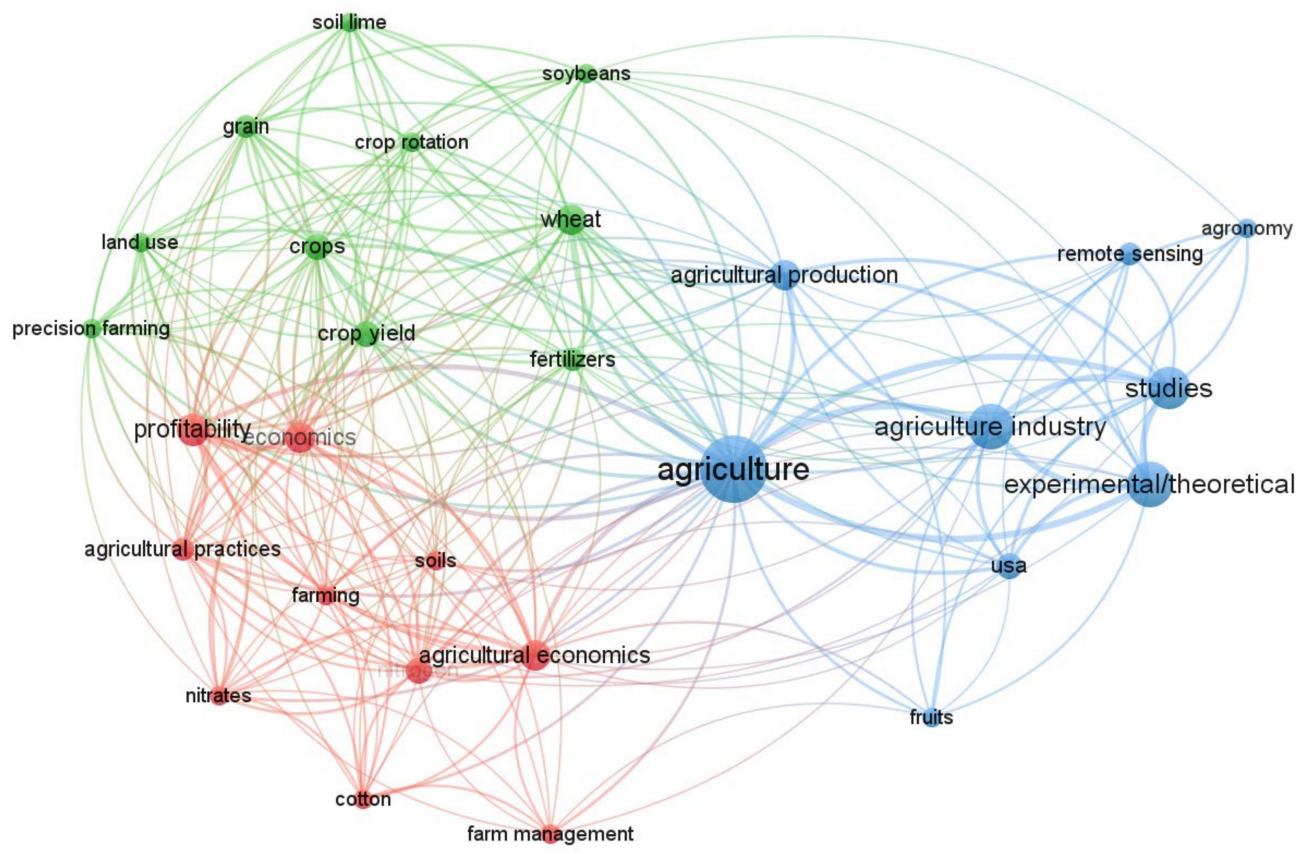

Figure 5. VOSviewer Analysis of Precision Agriculture (PA) Keyword Networks.

\subsection{Findings of Innovation Attributes}

Profitability and cost savings, yield and quality enhancement, and sustainability were three major benefits frequently discussed in the studies. Rogers' [31] five perceived attributes of innovation were employed to interpret the findings of technologies. Within each innovation attribute, several factors were the most prevalent in the investigated studies.

Relative advantage was illustrated, analyzed, inferred, and discussed in 29 of 31 publications. Out of 29 publications, 12 described the potential for PA adoption to reduce the amount of fertilizer usage and improve fertilizer efficiency. Stefanini et al. [43] utilized real-time on-thego optical sensing measurements (OPM) to evaluate the profitability and nitrogen efficiency. Torbett et al.'s [57] model also indicated that precision farmers found that PA technologies were important for improving fertilizer efficiency. Out of 29 publications, 15 concluded that adoption of PA applications could maintain profitability while reducing resource usage in the conventional practice, thus improving yield and quality. Boyer et al. [46] implemented plant sensing to determine the amount of nitrogen to apply in the field and found that the technology had the potential to reduce nitrogen costs or increase grain yield and production profit. Additionally, Young et al. [49] applied a computerized site-specific herbicide decision model in the field and explained that a reduction on the herbicide dose could continue to increase profits.

Compatibility was frequently included in the examined publications. Fourteen of 31 studies indicated that researchers applied the technologies based upon what farmers used in the field. Studies by both Stefanini et al. [43] and Boyer et al. [46] designed research for variablerate nitrogen management currently applied by farmers. Reyns et al. [50] employed previously developed sensors to obtain the grain yield data. Eight of 31 studies revealed that PA enhanced environmental protection by reducing fertilizer usage in which researchers applied the PA technologies based on what farmers had been using, and a match to the existing 
values that PA may lead to more sustainable cropping systems. Yost et al. [42] stated that even without profit gains, farmers should invest in PA to help environmental protection. Kountios et al. [68] concluded that farmers who had a better knowledge of PA would have a better acknowledgment of the environmental, economic, and social sustainability of PA.

There was one study explicitly addressing the complexity within 31 examined publications. Young et al. [49] stated that the computerized site-specific herbicide decision model was easy to use. In addition, Karatay and Meyer-Aurich [39] noted that their study needed to simplify complex production management to help with farmers' adoption of PA.

Trialability and observability were not explicitly addressed among studies, but 30 of 31 publications were conducted in on-farm trials or with computerized models. These results provided methods to replicate the PA application which would be considered as the attributes of trialability and observability. Figure 6 depicted the innovation attribute addressed among 31 examined studies.

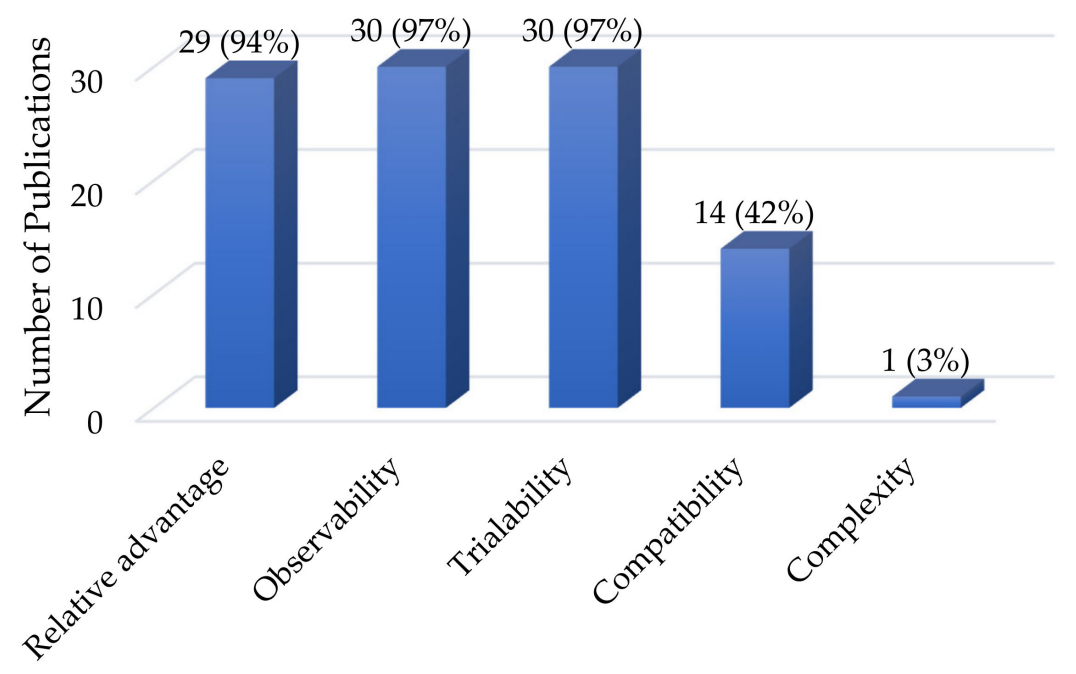

Innovation Attributes

Figure 6. Descriptive Statistics of Innovation Attributes $(n=31)$.

\section{Discussion}

The data presented here inform international agricultural extension agents with evidence to promote the adoption of PA. Characteristics of PA as an innovation include profitability and efficiency of resource use, production quality, and environmental sustainability as attributes. Agricultural commodities produced from PA technology ranged from wheat to peas. The majority of PA inquiries were conducted in the United States over the last twenty years, which was consistent with the rate of adoption in the United States. PA application allows farmers to better select crop varieties and allocate needed resources to reduce costs and increase profit margins. This study indicated that PA was relatively adopted in grain crops, such as wheat and corn, and legume crops, such as soybean, those often grown to increase the food crop production to address food security.

Rogers' [31] five perceived attributes of innovation explained the factors most PA technologies commonly aligned to increase the adoption of PA. We concluded that relative advantage and compatibility were two major factors that researchers considered to promote their innovation. If something is perceived as better than the innovation proceeding and compatible with farmers current situation, the rate of adoption will increase.

In this study, there were more publications targeted on improving profitability to promote PA adoption. The results of the keyword frequency revealed that profitability and economics were highly cited by researchers in the publication. Profitability motivates producers to adopt PA because the innovation meets farmers economic needs also contributing a relative advantage. 
Compatibility was another important reason that encouraged producers who adopt PA. The number of articles published with the "Improved the efficiency of resource use" theme was the second highest, which equates to Rogers' [31] compatibility that innovations align with the farmers' norm of belief and perspectives. Farmers' norms focus on producing crops in an efficient way, such as reducing the fertilizer usage amount, implementing more environmentally friendly production systems, or helping manual harvesting work, farmers are more likely to adopt for these reasons.

Co-occurrence analysis was implemented to obtain dominant keywords from PA adoption inquiries. Utilizing the VOSviewer tool, the researchers found clear themes on the diffusion trends. Our team identified three topic clusters of PA researchers, including profitability, crop, and agricultural economics, which demonstrate a research direction globally. The keyword frequency results denoted experimental and crop yield were highly cited in the publications that referred to Rogers' [31] trialability and observability attributes of the innovation. There were 30 of 31 articles analyzed in this study that described crop items in the experimental field which demonstrates the innovation to farmers. Improved profitability was the dominant theme that impacted sustainability of PA to improve farmers' income [70]. Producers could estimate and predict the yield and increase profit with PA applications.

The second dominant theme was improved efficiency of resource use related to farmers' concern about whether the PA technology was beneficial for producers to efficiently manage their manual labor and production materials [71,72]. Farmers who adopted PA were more efficient.

Theme three production quality indicated that farmers could use PA to improve the crop quality more precisely, such as by using the recommended amount of fertilizer based on the data, to have better market value on the production.

Technology's perceived complexity can be a factor slowing the rate of farmer adoption [31], and therefore, decreasing the odds of sustainability. None of the reviewed literature, except one inquiry, addressed the complexity of PA. This study revealed low PA complexity was the most poorly communicated adoption attribute, supporting Pathak et al.'s [24] finding that complexity is composed of multifarious exchanges. Through trialability and observability, it is imperative to demonstrate the ease of operation and cost of PA in comparison to increased efficiencies (cost-benefit analysis). However, if PA is perceived excessively complex or if complexity is unknown, farmers are likely to reject PA adoption [31]. So in essence, the attribute of complexity is about the adoption of technologies that are perceived as simple, or less complex. It is interesting that "ease of use" was not a prevalent theme.

\section{Conclusions}

With the continued increase in world population, limited capacity to expand the availability of natural resources (e.g., water and land), and a changing climate, there is a need to expand the adoption of precision agriculture approaches and tools. PA seeks to increase agricultural production without degrading natural resource quality and building resiliency of production systems to changing climate. Achieving these goals requires agricultural extensionists to promote innovative tools that quickly and reliably measure and monitor plant, soil, and atmospheric parameters in agricultural systems. As these tools and approaches are developed, it is important to train the current and future agricultural workforce, including educators, extension personnel, farmers, and ranchers with the advanced and necessary knowledge and skills in precision agriculture technologies. Using Rogers' attributes of an innovation as a theoretical lens to analyze research manuscripts, extension services can incorporate translation science to promote new practices.

This systematic literature review is exploratory and thus future research is needed to provide greater generalizability. As shown in Figure 2, our study found that wheat was the main crop variety of choice in promoting PA adoption, and PA adoption studies mainly were conducted in the United States. However, rice is one of the top production crops globally, yet none of the PA adoption literature focused on rice. China, India, and Indonesia are the three main rice-producing countries in the world and China is also one 
of the largest producers of wheat. However, PA adoption in China, India, and Indonesia were not present in the literature from the systematic review.

This study was conducted to understand PA adoption and the innovation's sustainability by farmers to support food production and increase food security. The agricultural extension system plays an important role in the diffusion process of agricultural innovation. The agricultural extension transfer process promotes education and training for farmers to assist in the adoption of PA innovations to advance agricultural development and provide sustainable solutions to agricultural issues [73]. However, zero literature matched the data extraction criteria from 12 agricultural extension journals, revealing that there was a chasm in the literature regarding agricultural extension agents, officers, or specialists' promotion of PA adoption. This finding is important due to the unknown of who is professionally developing agricultural extension field staff to promote PA adoption to target audiences. In addition to the who is the how. The data from this study's extension journal searches were void of how extension agents are trained to improve farmer PA adoption and assessing the adoption's impact. This speaks volumes if global agricultural extension field staff are expected to serve as change agents who promote and assess farmer PA adoption to improve local food security. Beyond the who and the how, is the first, and more appropriate question: are extension agents being professionally developed in the paradigm of farmer PA adoption? If not, sustainable PA adoption may never occur. The vast majority of PA adoption studies occurred in the U.S., but none of the studies indicated an extension agent knowledge transfer process. In addition to farmers, agricultural extension agents need education and training in PA adoption too.

The results of this study indicated previous inquiries did not fully examine the five attributes to predict PA adoption. It is likely these researchers are content experts and not familiar with change strategies, adoption and diffusion theory, or even translation science. In particular, our inquiry found researchers exercised relative advantage [24] and compatibility [27] as two dominant attributes to strengthen the adoption of PA. Improved profitability and efficiency were the driving factors of adoption uncovered in the systematic review juxtaposed to Pathak et al.'s findings [24]. This study provides a benchmark for partnerships with global extension services to promote adoption (when and if these systems are cultural appropriate). PA efficiencies can only impact stakeholders if the evidence from research is translated to the end users. International extension agents can act as translational scientists to increase communication channels for PA adoption primarily in trialability and observability. As a part of farmer field schools or extension workshops, the issue of "complexity" can be addressed by demonstrating and teaching farmers the ease of use of these technologies.

Author Contributions: Conceptualization, C.-L.L.; methodology, C.-L.L. and R.S.; literature review, C.-L.L.; discussions and conclusions development, C.-L.L.; formal analysis, C.-L.L.; data curation, C.-L.L.; writing—original draft preparation, C.-L.L.; writing—review and editing, R.S. and K.E.D. All authors have read and agreed to the published version of the manuscript.

Funding: This research received no external funding.

Institutional Review Board Statement: Not applicable.

Informed Consent Statement: Not applicable.

Data Availability Statement: No new data were created or analyzed in this study. Data sharing is not applicable to this article.

Conflicts of Interest: The authors declare no conflict of interest.

\section{References}

1. Thompson, R.J.; Storberg-Walker, J. Leadership and Power in International Development: Navigating the Intersections of Gender, Culture, Context, and Sustainability; Emerald Publishing Limited: Bingley, UK, 2018; p. 368. ISBN 978-1-7874-3999-3.

2. Godfray, H.C.J.; Beddington, J.R.; Crute, I.R.; Haddad, L.; Lawrence, D.; Muir, J.F.; Pretty, J.; Robinson, S.; Thomas, S.M.; Toulmin, C. Food Security: The Challenge of Feeding 9 Billion People. Science 2010, 327, 812-818. [CrossRef] [PubMed] 
3. Basso, B.; Dobrowolski, J.; McKay, C. From the Dust Bowl to Drones to Big Data: The Next Revolution in Agriculture. Georget. J. Int. Aff. 2017, 18, 158-165. [CrossRef]

4. Gallardo, R.K.; Sauer, J. Adoption of Labor-Saving Technologies in Agriculture. Annu. Rev. Resour. Econ. 2018, 10, 185-206. [CrossRef]

5. Zambon, I.; Cecchini, M.; Egidi, G.; Saporito, M.G.; Colantoni, A. Revolution 4.0: Industry vs. Agriculture in a Future Development for SMEs. Processes 2019, 7, 36. [CrossRef]

6. Wolde, Z.; Wei, W.; Kunpeng, W.; Ketema, H.; Wang, K. Local community perceptions toward livelihood and water-energy-food nexus: A perspective on food security. Food Energy Secur. 2020, 9, 1-15. [CrossRef]

7. Afzal, A.; Al-Subaiee, F.S.; Mirza, A.A. The Attitudes of Agricultural Extension Workers towards the Use of E-Extension for Ensuring Sustainability in the Kingdom of Saudi Arabia. Sustainability 2016, 8, 980. [CrossRef]

8. Arnés, E.; Díaz-Ambrona, C.G.H.; Marín-González, O.; Astier, M. Farmer Field Schools (FFSs): A tool for empowering sustainability and food security in peasant farming systems in the Nicaraguan Highlands. Sustainability 2018, 10, 3020. [CrossRef]

9. Materia, V.C.; Giarè, F.; Klerkx, L. Increasing Knowledge Flows between the Agricultural Research and Advisory System in Italy: Combining Virtual and Non-virtual Interaction in Communities of Practice. J. Agric. Educ. Ext. 2014, 21, 203-218. [CrossRef]

10. Jellason, N.P.; Conway, J.S.; Baines, R.N. Understanding impacts and barriers to adoption of climate-smart agriculture (CSA) practices in North-Western Nigerian drylands. J. Agric. Educ. Ext. 2021, 27, 55-72. [CrossRef]

11. Dunne, A.; Markey, A.; Kinsella, J. Examining the reach of public and private agricultural advisory services and farmers' perceptions of their quality: The case of county Laois in Ireland. J. Agric. Educ. Ext. 2019, 25, 401-414. [CrossRef]

12. Mourhir, A.; Papageorgiou, E.I.; Kokkinos, K.; Rachidi, T. Exploring Precision Farming Scenarios Using Fuzzy Cognitive Maps. Sustainability 2017, 9, 1241. [CrossRef]

13. Onyango, C.; Nyaga, J.; Wetterlind, J.; Söderström, M.; Piikki, K. Precision Agriculture for Resource Use Efficiency in Smallholder Farming Systems in Sub-Saharan Africa: A Systematic Review. Sustainability 2021, 13, 1158. [CrossRef]

14. Paustian, M.; Theuvsen, L. Adoption of precision agriculture technologies by German crop farmers. Precis. Agric. 2017, 18, 701-716. [CrossRef]

15. Balafoutis, A.; Beck, B.; Fountas, S.; Vangeyte, J.; Van Der Wal, T.; Soto, I.; Gómez-Barbero, M.; Barnes, A.; Eory, V. Precision Agriculture Technologies Positively Contributing to GHG Emissions Mitigation, Farm Productivity and Economics. Sustainability 2017, 9, 1339. [CrossRef]

16. Loures, L.; Chamizo, A.; Ferreira, P.; Loures, A.; Castanho, R.; Panagopoulos, T. Assessing the Effectiveness of Precision Agriculture Management Systems in Mediterranean Small Farms. Sustainability 2020, 12, 3765. [CrossRef]

17. Ullah, A.; Nawaz, A.; Farooq, M.; Siddique, K. Agricultural Innovation and Sustainable Development: A Case Study of Rice-Wheat Cropping Systems in South Asia. Sustainability 2021, 13, 1965. [CrossRef]

18. Yue, Y.; Zhou, Y.; Wang, J.; Ye, X. Assessing wheat frost risk with the support of GIS: An approach coupling and growing season meterological index and a hybrid fuzzy neutral network model. Sustainability 2016, 8, 1308. [CrossRef]

19. International Society of Precision Agriculture. Precision ag Definition: International Society of Precision Agriculture; International Society of Precision Agriculture: Monticello, IL, USA, 2019; Available online: https://www.ispag.org/about/definition (accessed on 13 July 2021).

20. Bosompem, M. Potential challenges to precision agriculture technologies development in Ghana: Scientists' and cocoa extension agents' perspectives. Precis. Agric. 2021, 22, 1578-1600. [CrossRef]

21. Bramley, R.G.V. Lessons from nearly 20 years of Precision Agriculture research, development, and adoption as a guide to its appropriate application. Crop Pasture Sci. 2009, 60, 197-217. [CrossRef]

22. Fountas, S.; Pedersen, S.M.; Blackmore, S. ICT in Precision Agriculture—Diffusion of Technology an Overview of Precision Agriculture ICT in Agriculture: Perspective of Technological Innovation; Gelb, E., Offer, A., Eds.; ResearchGate: Berlin, Germany, 2004. [CrossRef]

23. Schimmelpfennig, D.; Ebel, R. Sequential Adoption and Cost Savings from Precision Agriculture. J. Agric. Resour. Econ. 2016, 41, 97-115. Available online: http:/ / www.jstor.org/stable/44131378 (accessed on 22 April 2021).

24. Pathak, H.S.; Brown, P.; Best, T. A systematic literature review of the factors affecting the precision agriculture adoption process. Precis. Agric. 2019, 20, 1292-1316. [CrossRef]

25. Kernecker, M.; Knierim, A.; Wurbs, A.; Kraus, T.; Borges, F. Experience versus expectation: Farmers' perceptions of smart farming technologies for cropping systems across Europe. Precis. Agric. 2020, 21, 34-50. [CrossRef]

26. Lowenberg-DeBoer, J.; Erickson, B. Setting the Record Straight on Precision Agriculture Adoption. Agron. J. 2019, 111, 1552-1569. [CrossRef]

27. Robertson, M.J.; Llewellyn, R.; Mandel, R.; Lawes, R.; Bramley, R.; Swift, L.; Metz, N.; O'Callaghan, C. Adoption of variable rate fertiliser application in the Australian grains industry: Status, issues and prospects. Precis. Agric. 2012, 13, 181-199. [CrossRef]

28. Sarri, D.; Lombardo, S.; Pagliai, A.; Perna, C.; Lisci, R.; De Pascale, V.; Rimediotti, M.; Cencini, G.; Vieri, M. Smart Farming Introduction in Wine Farms: A Systematic Review and a New Proposal. Sustainability 2020, 12, 7191. [CrossRef]

29. Cosby, A.M.; Falzon, G.A.; Trotter, M.G.; Stanley, J.N.; Powell, K.S.; Lamb, D.W. Risk mapping of redheaded cockchafer (Adoryphorus couloni) (Burmeister) infestations using a combination of novel k-means clustering and on-the-go plant and soil sensing technologies. Precis. Agric. 2016, 17, 1-17. [CrossRef]

30. Rogovska, N.; Laird, D.A.; Chiou, C.-P.; Bond, L.J. Development of field mobile soil nitrate sensor technology to facilitate precision fertilizer management. Precis. Agric. 2019, 20, 40-55. [CrossRef] 
31. Rogers, E.M. Diffusion of Innovations, 5th ed.; Free Press: New York, NY, USA, 2003; p. 551. ISBN 978-0-7432-2209-9.

32. Luck, J.; Fulton, J.; Rees, J. Hands-On Precision Agriculture Data Management Workshops for Producers and Industry Professionals: Development and Assessment. 2015, Volume 53. Available online: https://archives.joe.org/joe/2015august/tt10.php (accessed on 26 April 2021).

33. Asseng, S.; Asche, F. Future farms without farmers. Sci. Robot. 2019, 4, eaaw1875. [CrossRef]

34. Saiz-Rubio, V.; Rovira-Más, F. From Smart Farming towards Agriculture 5.0: A Review on Crop Data Management. Agronomy 2020, 10, 207. [CrossRef]

35. Vindrola-Padros, C.; Brage, E.; Johnson, G.A. Rapid, Responsive, and Relevant? A Systematic Review of Rapid Evaluations in Health Care. Am. J. Eval. 2021, 42, 13-27. [CrossRef]

36. Wright, R.W.; A Brand, R.; Dunn, W.; Spindler, K.P. How to Write a Systematic Review. Clin. Orthop. Relat. Res. 2007, 455, 23-29. [CrossRef]

37. Ravikumar, S.; Agrahari, A.; Singh, S.N. Mapping the intellectual structure of scientometrics: A co-word analysis of the journal Scientometrics (2005-2010). Scientometrics 2015, 102, 929-955. [CrossRef]

38. Chen, X.; Chen, J.; Wu, D.; Xie, Y.; Li, J. Mapping the Research Trends by Co-word Analysis Based on Keywords from Funded Project. Procedia Comput. Sci. 2016, 91, 547-555. [CrossRef]

39. Karatay, Y.N.; Meyer-Aurich, A. Profitability and downside risk implications of site-specific nitrogen management with respect to wheat grain quality. Precis. Agric. 2020, 21, 449-472. [CrossRef]

40. Mills, B.E.; Brorsen, W.; Arnall, D.B. The profitability of variable rate lime in wheat. Precis. Agric. 2020, 21, 369-386. [CrossRef]

41. Stamatiadis, S.; Schepers, J.S.; Evangelou, E.; Glampedakis, A.; Dercas, N.; Tsadilas, C.; Tserlikakis, N.; Tsadila, E. Variable-rate application of high spatial resolution can improve cotton N-use efficiency and profitability. Precis. Agric. 2020, $21,695-712$. [CrossRef]

42. Yost, M.A.; Kitchen, N.R.; Sudduth, K.A.; Massey, R.E.; Sadler, E.J.; Drummond, S.T.; Volkmann, M.R. A long-term precision agriculture system sustains grain profitability. Precis. Agric. 2019, 20, 1177-1198. [CrossRef]

43. Stefanini, M.; Larson, J.A.; Lambert, D.M.; Yin, X.; Boyer, C.N.; Scharf, P.; Tubaña, B.S.; Varco, J.J.; Dunn, D.; Savoy, H.J.; et al. Effects of optical sensing based variable rate nitrogen management on yields, nitrogen use and profitability for cotton. Precis. Agric. 2019, 20, 591-610. [CrossRef]

44. Tona, E.; Calcante, A.; Oberti, R. The profitability of precision spraying on specialty crops: A technical-economic analysis of protection equipment at increasing technological levels. Precis. Agric. 2018, 19, 606-629. [CrossRef]

45. Larson, J.A.; Velandia, M.M.; Buschermohle, M.J.; Westlund, S.M. Effect of field geometry on profitability of automatic section control for chemical application equipment. Precis. Agric. 2016, 17, 18-35. [CrossRef]

46. Boyer, C.N.; Brorsen, B.W.; Solie, J.B.; Raun, W. Profitability of variable rate nitrogen application in wheat production. Precis. Agric. 2011, 12, 473-487. [CrossRef]

47. Maine, N.; Lowenberg-DeBoer, J.; Nell, W.T.; Alemu, Z.G. Impact of variable-rate application of nitrogen on yield and profit: A case study from South Africa. Precis. Agric. 2010, 11, 448-463. [CrossRef]

48. O'Neal, M.; Frankenberger, J.R.; Ess, D.R.; Lowenberg-DeBoer, J. Profitability of On-Farm Precipitation Data for Nitrogen Management Based on Crop Simulation. Precis. Agric. 2004, 5, 153-178. [CrossRef]

49. Young, D.L.; Kwon, T.J.; Smith, E.G.; Young, F.L. Site-Specific Herbicide Decision Model to Maximize Profit in Winter Wheat. Precis. Agric. 2003, 4, 227-238. [CrossRef]

50. Reyns, P.; Spaepen, P.; De Baerdemaeker, J. Site-Specific Relationship Between Grain Quality and Yield. Precis. Agric. 2000, 2, 231-246. [CrossRef]

51. Martínez, J.; Egea, G.; Agüera, J.; Pérez-Ruiz, M. A cost-effective canopy temperature measurement system for precision agriculture: A case study on sugar beet. Precis. Agric. 2017, 18, 95-110. [CrossRef]

52. Pavuluri, K.; Chim, B.K.; Griffey, C.A.; Reiter, M.S.; Balota, M.; Thomason, W.E. Canopy spectral reflectance can predict grain nitrogen use efficiency in soft red winter wheat. Precis. Agric. 2015, 16, 405-424. [CrossRef]

53. Ampatzidis, Y.G.; Whiting, M.D.; Liu, B.; Scharf, P.A.; Pierce, F.J. Portable weighing system for monitoring picker efficiency during manual harvest of sweet cherry. Precis. Agric. 2013, 14, 162-171. [CrossRef]

54. Ortiz, B.V.; Balkcom, K.B.; Duzy, L.; Van Santen, E.; Hartzog, D.L. Evaluation of agronomic and economic benefits of using RTK-GPS-based auto-steer guidance systems for peanut digging operations. Precis. Agric. 2013, 14, 357-375. [CrossRef]

55. Gómez-candón, D.; López-granados, F.; Caballero-novella, J.J.; García-ferrer, A.; Peña-barragán, J.M.; Jurado-expósito, M.; García-torres, L. Sectioning remote imagery for characterization of Avena sterilis infestations. Part B: Efficiency and economics of control. Precis. Agric. 2012, 13, 337-350. [CrossRef]

56. Rascher, U.; Pieruschka, R. Spatio-temporal variations of photosynthesis: The potential of optical remote sensing to better understand and scale light use efficiency and stresses of plant ecosystems. Precis. Agric. 2008, 9, 355-366. [CrossRef]

57. Torbett, J.C.; Roberts, R.K.; Larson, J.A.; English, B.C. Perceived importance of precision farming technologies in improving phosphorus and potassium efficiency in cotton production. Precis. Agric. 2007, 8, 127-137. [CrossRef]

58. Biermacher, J.T.; Epplin, F.M.; Brorsen, B.W.; Solie, J.B.; Raun, W.R. Maximum benefit of a precise nitrogen application system for wheat. Precis. Agric. 2006, 7, 193-204. [CrossRef]

59. Krell, R.K.; Pedigo, L.P.; Babcock, B.A. Comparison of Estimated Costs and Benefits of Site-Specific Versus Uniform Management for the Bean Leaf Beetle in Soybean. Precis. Agric. 2003, 4, 401-411. [CrossRef] 
60. Holland, J.E.; Cammarano, D.; Fitzgerald, G.J.; Perry, E.M.; Poile, G.; Conyers, M.K. Proximal fluorescence sensing of potassium responsive crops to develop improved predictions of biomass, yield and grain quality of wheat and barley. Precis. Agric. 2019, 20, 379-397. [CrossRef]

61. Uribeetxebarria, A.; Martínez-Casasnovas, J.A.; Escolà, A.; Rosell-Polo, J.R.; Arnó, J. Stratified sampling in fruit orchards using cluster-based ancillary information maps: A comparative analysis to improve yield and quality estimates. Precis. Agric. 2019, 20, 179-192. [CrossRef]

62. Arnó, J.; Rosell, J.R.; Blanco, R.; Ramos, M.C.; Martínez-Casasnovas, J.A. Spatial variability in grape yield and quality influenced by soil and crop nutrition characteristics. Precis. Agric. 2012, 13, 393-410. [CrossRef]

63. Aggelopoulou, K.D.; Wulfsohn, D.; Fountas, S.; Gemtos, T.A.; Nanos, G.D.; Blackmore, S. Spatial variation in yield and quality in a small apple orchard. Precis. Agric. 2010, 11, 538-556. [CrossRef]

64. Link, J.; Batchelor, W.D.; Graeff, S.; Claupein, W. Evaluation of current and model-based site-specific nitrogen applications on wheat (Triticum aestivum L.) yield and environmental quality. Precis. Agric. 2008, 9, 251-267. [CrossRef]

65. Jørgensen, J.R.; Jørgensen, R.N. Uniformity of wheat yield and quality using sensor assisted application of nitrogen. Precis. Agric. 2007, 8, 63-73. [CrossRef]

66. Miao, Y.; Mulla, D.J.; Robert, P.C. Spatial Variability of Soil Properties, Corn Quality and Yield in Two Illinois, USA Fields: Implications for Precision Corn Management. Precis. Agric. 2006, 7, 5-20. [CrossRef]

67. Miao, Y.; Mulla, D.J.; Robert, P.C. Identifying important factors influencing corn yield and grain quality variability using artificial neural networks. Precis. Agric. 2006, 7, 117-135. [CrossRef]

68. Kountios, G.; Ragkos, A.; Bournaris, T.; Papadavid, G.; Michailidis, A. Educational needs and perceptions of the sustainability of precision agriculture: Survey evidence from Greece. Precis. Agric. 2018, 19, 537-554. [CrossRef]

69. Bongiovanni, R.; Lowenberg-Deboer, J. Precision Agriculture and Sustainability. Precis. Agric. 2004, 5, 359-387. [CrossRef]

70. Lin, P.; Lee, W.S.; Chen, Y.M.; Peres, N.; Fraisse, C. A deep-level region-based visual representation architecture for detecting strawberry flowers in an outdoor field. Precis. Agric. 2020, 21, 387-402. [CrossRef]

71. Jensen, H.G.; Jacobsen, L.-B.; Pedersen, S.M.; Tavella, E. Socioeconomic impact of widespread adoption of precision farming and controlled traffic systems in Denmark. Precis. Agric. 2012, 13, 661-677. [CrossRef]

72. Silva, C.B.; De Moraes, M.A.F.D.; Molin, J.P. Adoption and use of precision agriculture technologies in the sugarcane industry of São Paulo state, Brazil. Precis. Agric. 2011, 12, 67-81. [CrossRef]

73. Altalb, A.A.T.; Filipek, T.; Skowron, P. The role of agricultural extension in the transfer and adoption of agricultural technologies. Asian J. Agric. Food Sci. 2015, 3, 500-507. Available online: https://ajouronline.com/index.php/AJAFS/article/view/2962 (accessed on 26 April 2021) 